\title{
RELIGIOSITY, FINANCIAL KNOWLEDGE, AND FINANCIAL BEHAVIOR INFLUENCE ON PERSONAL FINANCIAL DISTRESS AMONG MILLENNIAL GENERATION
}

\author{
Nelson Lajuni ${ }^{1 *}$, Imbarine Bujang ${ }^{2}$, Abd. Aziz Karia ${ }^{3}$, Yusman Yacob ${ }^{4}$ \\ ${ }^{1,2,3,4}$ Faculty of Business, Economics and Accountancy, Universiti Malaysia Sabah, Malaysia. \\ *Corresponding author; Email: nelson@ums.edu.my
}

\begin{abstract}
This study attempts to examine the personal financial distress among Malaysians millennial generation by scrutinizing religiosity, financial knowledge, and financial behavior as the influencing antecedents. The study adopted social learning theory (SLT) to underpin and explain the conceptual framework. The data were collected from millennial generations in Malaysia and analysed using Partial Least Squares Structural Equation Modelling. The findings suggest that all claimed hypotheses were partially supported. Implication and contribution of the study were later discussed to justify the significance of this research. The findings revealed that behavioral traits to have a stronger impact on the incidence of personal financial distress than religiosity or financial knowledge. The results suggested the government should implement policy that could be oriented towards improving the financial habits and mitigating the impact of behavioral characteristics on personal finances.
\end{abstract}

Keywords: Social learning theory, religiosity, financial knowledge, financial behavior, financial distress.

\section{Introduction}

Social scientists have always been fascinated on the determinants of personal financial distress of individuals. Although social scientists may not be able to decompose all fixed effects of financial distress but it is vital to better understand how the sources of individual variation such as religiosity, financial knowledge, and financial behavior contribute towards personal financial distress of young adults in Malaysia. There are many important decisions made for the first time by individual especially on financial matters when they enter adulthood. The financial behavior for example has general implications towards young adulthood as they extend throughout adulthood up to later life and determine individual lifelong financial outcomes (Eccles, Ward, Goldsmith, \& Arsal, 2013).

The young adults of today face a set of challenges which include limited financial resources and rising cost of living. Hence, the knowledge in personal financial management is vital to help the young adults make the right decisions about their financial management. This is because they are confronted with challenges such as the demand to have savings for emergencies, management of credit and risks, plans for retirement, and management of property. Failure to cope with the challenges can contribute to emotional stress (Socyberty, 2006; Scott, 2010). Financial stress can lead to poor performance and motivation at work, as well as physical and mental health leading to stress and further bring about the negative impact towards performance at the workplace (Prawitz \& Garman, 2009).

Evidence from the statistics pertaining to youths' financial situations has become a great concern to many stakeholders. According to the Malaysian Insolvency Department (MID), there is an upsurge of 25 percent on insolvency between the period of 2005 and December 2010 that involved youths aged between 25 and 44. Moreover, a study by Yew, Yong, Cheong, and Tey (2017) also highlighted the magnitude of youths' personal financial difficulties as there were an increase in bankruptcy among younger Malaysians (The Malaysian Insider, 2014). Therefore, in this paper, we explore how religiosity, financial knowledge and financial behavior, explain individual financial distress and the mediating effects of financial behavior towards financial distress in young adulthood.

\section{Social Learning Theory}

Social Learning Theory that explains how individuals learn behavior was introduced by Bandura (1969) which accentuates the role of both human development and cognitive. The theory holds that individual learns by observing the behaviors of others and mimicking and modelling their behavior. Social scientists in consumer-related fields have adopted Social Learning Theory in their studies to elucidate compulsive behavior (Valence, D'Astous, 
\& Fourtier, 1988) and financial behavior (Hira, 1997; Martin \& Bush, 2000; Gutter, Garrison, \& Copur, 2010). At the same time, religiosity, financial behavior, and financial knowledge are ex-pected to have direct effects on financial distress (Cude et al., 2006).

\section{Financial Distress}

Financial distress is a subjective phenomenon. Two individuals in the same financial situation may have different levels of perceived financial distress. Distress about financial matters is increasingly prevalent in society, with half or more adults reporting moderate to high levels of stress and worry about money matters in survey after survey (American Express Financial Services, 2004; MetLife Insurance Company, 2003). Previous studies on financial stress concern about personal finances linked to health (Bagwell \& Kim, 2003; Drentea, 2000; Drentea \& Lavrakas, 2000; Jacobson, et al., 1996; O’Neill, 2004; O'Neill, Xiao, Sorhaindo, \& Garman, 2005a, 2005b, 2005c). Financial distress also has been associated with lower self-esteem (Kernis, Grannemann \& Mathis, 1991) and dissatisfaction with one's financial situation (Garman et al., 2005a; Garman, \& Sorhaindo, 2005). Previous studies exposed that insufficient income and inefficient cashflow management behavior resulted financial distress (Eccles et al., 2013). To succeed, one should be able to formulate and implement financial plan (Yao \& Xu, 2015), resist temptation (Gathergood, 2012; Gul \& Pesendorfer, 2004; Thaler \& Shefrin, 1981), and deal with social comparison (Brown \& Laschever, 2012; Bursztyn, Ederer, Ferman, \& Yuchtman, 2012).

\section{Religiosity}

One of the most universal and influential social institutions is religion. In fact, according to Shweder (1991), religion has a substantial influence on people's attitudes, values, and behaviors both at the individual and societal level. Sabri and Falahati (2014) found there were dissimilarities between Muslim and Non-Muslim respondents. The results reveal higher effect of secondary socialization or influencer agents on Non-Muslim respondents, while for Muslim respondents, the effect of their financial knowledge and primary socialization agents, including parents and religion is greater. John (1999) and Hira (1997) defined secondary socialization agents comprised agents such as magazines, mass media, advertisements, peer group, mobile phones and the Internet while primary socialization agents comprised mother, father, si- blings, school and religion. Even though there were considerable literature focused on culture and its influence on various aspects of consumer behavior (Mokhlis, 2009), little research has examined the effect of religion specifically on financial behavior, financial knowledge, or especially on financial distress.

\section{Financial Knowledge}

Previous studies indicate that financial knowledge level in developing countries are lower compared to that of developed countries (Hastings \& Tejeda-Ashton, 2008; Cole, Sampson, \& Zia, 2011; Klapper \& Panos; 2011; Beckmann, 2013). Even though, many studies revealed that an individual with a high level of financial know-ledge may not necessarily have a positive self-perception of his knowledge level or good at managing their finances (Asaad, 2015; Hadar, Sood, \& Fox, 2013; Parker, De Bruin, Yoong, \& Willis, 2012), we decide to include financial knowledge as past studies show it could encourage positive financial behaviors such as paying bill on time, having savings and investment, ability to manage credit cards wisely (Lusardi, Mitchell, \& Curto, 2010; Danes \& Haberman, 2007; Laily, 2014, \& Susanti, 2013), having proper retirement plan (Klapper \& Panos, 2011), greater participation in financial markets, greater use of formal sources of borrowing (Klapper, Lusardi, \& Panos, 2013), higher voluntary savings (Landerretche \& Martinez, 2013) and better diversification (Beckmann, 2013).

\section{Financial Behavior}

Financial management frequently repre-sents as specific behaviors, such as paying bills on time, saving money for future planning such as emergencies and retirement, and avoiding too much debt (Brown \& Taylor, 2014). Ever since the financial crisis in 2008, the study of financial knowledge especially on its components such as attitudes and behavior has gained a lot of attention and limelight. Social scientists have acknowledged how well to effectively predict financial and economic processes depend on how we could understand the attitudes and behaviors of the society towards finances, as well as the characteristics of various social groups sharing the same views and behaviors (Németh \& Zsótér, 2017). Thus, examining the financial behavior of young adults is an interesting and important research topic well worth scrutinised from various aspects (Zsótér, 2017) as young adults face crucial predicaments and have to handle sophisticated financial decisions at every stage of their life cycle (Sundarasen \& Rahman, 2017). 
Framework and Hypothesis Development

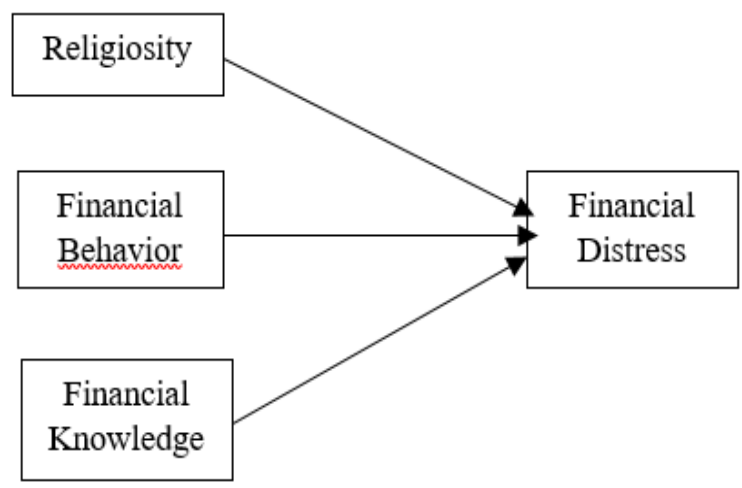

Figure 1. Research framework

Thus, seven hypotheses were formulated to direct the research problems and aims of the study.

$H_{l}$ : Religiosity negatively influences financial distress.

$H_{2}$ : Financial behavior negatively influences financial distress.

$H_{3}$ : Financial knowledge negatively influences financial distress.

$H_{4}$ : Religiosity positively influences financial knowledge.

$H_{5}$ : Financial knowledge positively influences financial behavior.

$H_{6}$ : Religiosity negatively influence financial distress mediated by financial behavior.

$H_{7}$ : Financial knowledge negatively influence financial distress mediated by financial behavior.

\section{Research Method}

The samples for this study were young adults in Malaysia aged between 19-27. To ensure that the sample characteristics corresponded to the nature of the study, a non-probability purposive sampling technique was adopted to ensure the collected data were indeed from valid sources. Sample size estimation is determined using G*power 3.0 analysis (Faul, Erdfelder, Lang, \& Buchner, 2007). By using G-Power Analysis software, with the effect size of $f$ square $0.15, \alpha$ error pro 0.05 , power Gf 0.95 with a number of five tested predictors, therefore 153 respondents are the minimum sampling for this study. 400 questionnaires were distributed; and 304 completed and usable copies were collected. Figure 1 depicted the research framework that contained statements of four variables investigated. The variables are assessed using multiple items (Hayduk \& Littvay, 2012) and the data was then analysed using SmartPLS 3.0 (Ringle, Wende, $\&$ Will, 2015) to examine the hypotheses.

\section{Result}

With a total of 304 respondents made up of millennial generation in Malaysia, the majority of the respondents were female $(61.5 \%)$ and the remaining were male respondents (38.5\%). 96.7 percent of the respondents were between 19-24 years old. More than 63 per cent were east Malaysians (Sabah and Sarawak) followed by those from west Malaysians 36.2 per cent. The Sabahan made up the largest ethnic (32.2\%) followed by Chinese (28\%), Malays (25.7\%), Sarawakians (10.5\%), Indian (2\%), and other (1.6\%) group of ethnics. The respondent profile was summarized in a report shown in Table 1.

Table 1

Respondents' Profile

\begin{tabular}{llcc}
\hline Variable & & Frequency & Percent \\
\hline Gender & Male & 117 & 38.5 \\
& Female & 187 & 61.5 \\
Age & $19-21$ & 140 & 46.1 \\
& $22-24$ & 154 & 50.6 \\
& $25-27$ & 10 & 3.3 \\
Region & Peninsular Malaysia & 110 & 36.2 \\
& Sabah & 134 & 44.1 \\
& Sarawak & 60 & 19.7 \\
Ethnicity & Malay & 78 & 25.7 \\
& Chinese & 85 & 28.0 \\
& Indian & 6 & 2.0 \\
& Sabah Natives & 98 & 32.2 \\
& Sarawak Natives & 32 & 10.5 \\
& Other & 5 & 1.6 \\
\hline
\end{tabular}

\section{Measurement Model Assessment}

Table 2 demonstrates the findings of construct reliability (CR) and convergent validity testing. The results validate that the constructs (or variables under investigation) have high and sufficient average variance extracted internal consistency (Roldán \& Sánchez-Franco, 2012) (AVE) to validate the convergent validity (Hair, Hult, Ringle, \& Sarstedt, 2017).

HTMT criterion is used to assess discriminant validity (Ringle, et al., 2015) as shown in Table 3. The result specifies that the discriminant validity is well-established at HTMT0.85 (Diamantopoulos \& Siguaw, 2006). Thus, there is no issue of multi-collinearity between items loaded on different constructs in the outer model. Hence, it is appropriate to proceed to structural model assessment so as to test the hypotheses of the study. 
Table 2

Measurement Model Assessment

\begin{tabular}{|c|c|c|c|c|c|}
\hline Construct & Item & Loadings & CR & AVE & $\begin{array}{c}\text { Convergent } \\
\text { Validity } \\
(\text { Ave }>0.5)\end{array}$ \\
\hline Financial & FB2 & 0.803 & 0.794 & 0.659 & Yes \\
\hline \multirow[t]{3}{*}{ Behavior } & FB3 & 0.820 & & & \\
\hline & FD5 & 0.771 & & & \\
\hline & FD3 & 0.778 & & & \\
\hline Financial & FD2 & 0.740 & 0.919 & 0.588 & Yes \\
\hline \multirow[t]{4}{*}{ Distress } & FD6 & 0.800 & & & \\
\hline & FD7 & 0.756 & & & \\
\hline & FD8 & 0.760 & & & \\
\hline & FD9 & 0.800 & & & \\
\hline Financial & FK1 & 0.886 & 0.733 & 0.586 & Yes \\
\hline \multirow[t]{2}{*}{ nowledge } & FK2 & 0.622 & & & \\
\hline & $\mathrm{R} 1$ & 0.913 & & & \\
\hline Religiosity & R3 & 0.961 & 0.935 & 0.878 & Yes \\
\hline
\end{tabular}

Criteria: Composite Reliability >0.708 (Hair et al., 2017), (Hair et al., 2017) AVE> 0.5 (Hair et al., 2017), (Hair et al., 2017).

Table 3

HTMT Criterion

\begin{tabular}{lcccc}
\hline & $\begin{array}{c}\text { Financial Financia } \\
\text { Behavior I Distress }\end{array}$ & $\begin{array}{c}\text { Financial } \\
\text { Know- } \\
\text { ledge }\end{array}$ & $\begin{array}{c}\text { Relig } \\
\text { iosity }\end{array}$ \\
\hline Financial & & & & \\
Behavior & - & & & \\
$\begin{array}{l}\text { Financial } \\
\text { Distress }\end{array}$ & 0.416 & - & & \\
Financial & & & & - \\
Knowledge & 0.447 & 0.507 & - & \\
Religiosity & 0.123 & 0.163 & 0.533 & - \\
\hline
\end{tabular}

Criteria: Discriminant validity is established at HTMT0.85 / HTMTO.90

\section{Structural Model Assessment}

To assess the hypotheses, a 5000-bootstrap resampling of data is conducted (Hair et al., 2017). Table 4 demonstrates the assessment of the path coefficient, which is represented by Beta values for each path relationship. The results show five out of seven hypotheses were supported. Financial behavior and financial knowledge are found to have influence on personal financial distress. The study also revealed that religiosity and financial knowledge did influence financial behavior. As such, hypotheses 2, 3, 4, and 5 were supported. This study also examined financial behavior as mediator to religiosity and financial knowledge towards personal financial distress. The mediating effects of financial behavior only worked between religiosity and financial distress. Thus, hypothesis 6 is also supported. Table 4 also displays the quality of the model. On the hypotheses which are tested to have significant relationships, all are found to have carried moderate effect size. The predictive relevance values for all four dependent variables are larger than 0 , indicating that the independent variables are capable of predicting the youth's financial distress, as presented by $Q^{2}$ using blindfolding procedure (Hair et al., 2017).

\section{Discussion}

The study utilises Social Learning Theory to explain how financial distress of young adults were influenced by their religiosity, financial knowledge, and financial behavior. The present study sets out to contribute to the success of financial educational programmes, initiated by either the public sector (financial education) or the private sector, with the purpose to improve the level of financial knowledge in Malaysia. We expect that the number of people facing financial difficulties will increase in future. This situation is disturbing, as the implications will not only affect individuals, but also cause in enormous costs for the entire financial system. Therefore, it is crucial for the policymakers to understand precisely why people get involve into financial trouble, so that appropriate action or policy could be devised to prevent people from getting into difficulties in the future (McCarthy, 2011).

Therefore, financial education among public young generation cannot be taken for granted and immediate correction measures need to be considered to ensure they are equipped with financial knowledge before leaving learning or training institutions. These young adults need assistance to make wise financial decisions in future and at the same time, the relevant authorities have to realize that a "one-time or onesize-fits-all" financial education program is likely to be ineffective to improve financial distress of future generation. Thus, understanding financial distress among young people is vital such as devising effective financial education programs targeted at young to protect younger consumers so that bankruptcy cases could be reduced through improving financial education.

As the study showed that religiosity and financial knowledge have a significant effect on the young adults' financial behavior and eventually relieve financial distress, the government should support religious and financial education activities that could contribute to help the community elevate their financial knowledge level. At the same time, religious authorities must also play their part by conducting not only religious related activities for spiri- 
Table 4

Path Coefficients and Model Quality Assessment

\begin{tabular}{|c|c|c|c|c|c|c|c|c|c|c|c|}
\hline Direct Effect & Beta & S.E. & t-Value & p-value & $5.00 \%$ & $95.00 \%$ & Decision & $f^{2}$ & $R^{2}$ & VIF & $Q^{2}$ \\
\hline$H_{I}$ Religiosity->Financial Distress & 0.133 & 0.049 & 2.716 & 0.003 & 0.056 & 0.212 & Not Supported & 0.020 & 0.150 & 1.059 & 0.078 \\
\hline $\mathrm{H}_{2}$ : Financial Behavior-> Financial & -0.251 & 0.044 & 5.674 & 0.000 & -0.326 & -0.181 & Supported & 0.070 & & 1.055 & \\
\hline $\begin{array}{l}H_{3}: \text { Financial Knowledge-> Financial } \\
\text { Distress }\end{array}$ & 0.209 & 0.052 & 4.040 & 0.000 & 0.135 & 0.301 & Supported & 0.047 & & 1.091 & \\
\hline$H_{4}:$ Religiosity $>$ Financial Behavior & 0.126 & 0.053 & 2.395 & 0.009 & 0.042 & 0.218 & Supported & 0.016 & 0.052 & 1.042 & 0.029 \\
\hline $\begin{array}{l}H_{5} \text { : Financial Knowledge }>\text { Financial } \\
\text { Behavior }\end{array}$ & -0.217 & 0.052 & 4.175 & 0.000 & -0.305 & -0.133 & Supported & 0.047 & & 1.042 & \\
\hline Indirect Effect & Beta & S.E. & t-Value & p-value & $5.00 \%$ & $95.00 \%$ & Decision & & & & \\
\hline$H_{6}:$ Religiosity $>$ Financial Distress & -0.032 & 0.015 & 2.101 & 0.018 & -0.059 & -0.009 & Supported & & & & \\
\hline $\begin{array}{l}H_{7} \text { : Financial Knowledge }>\text { Financial } \\
\text { Distress }\end{array}$ & 0.054 & 0.016 & 3.336 & 0.000 & 0.033 & 0.082 & Not Supported & & & & \\
\hline
\end{tabular}

Lateral Collinearity: VIF 3.3 or higher (Diamantopoulos \& Sigouw, 2006)

$R^{2} \geq 0.26$ consider Substantial (Cohen, 1989)

$F^{2} \geq 0.26$ consider Substantial (Cohen, 1989)

$Q^{2}>0.00$ consider large (Hair et al., 2017)

tual needs but also conducting activities on financial knowledge e.g. inserting finance related topics in seminars, talks or workshops when conducting religious activities such as pre-marriage seminar usually conducted by Islamic or Christian authorities in Malaysia.

\section{Conclusion}

Future study should also consider other potential determinants that may enhance financial knowledge and improve financial behavior of millennial generation in Malaysia so they could face financial distress in a wiser and matured manner. The social media for example is widely used by this generation to get information. The fact of having 68.6 percent Internet penetration with more than 21 million Internet users with almost 30.8 million population (Internet World Stats, 2017) and at the same time being the world highest user of WhatsApp (Bernama, 2017), Malaysian's authority should utilise social media as a platform to educate the public especially the young adults on the importance of financial knowledge to the society. The stakeholders must act now to find way on how social media can be utilised to manoeuvre the financial knowledge and financial behavior in Malaysia for the benefit and well-being of the nation.

\section{References}

American Express Financial Services. (2004, April 1). $2^{\text {nd }}$ American Express national survey finds worker financial stress lingering into 2004. Press release.

Asaad, C. T. (2015). Financial literacy and financial behavior: Assessing knowledge and confidence. Financial Services Review, 24, 101-117.

Bandura, A. (1969). Principles of behaviour modification. New York: Holt, Rinehart, and Winston.
Bagwell, D. C., \& Kim, J. (2003). Financial stress, health status, and absenteeism in credit counseling clients. Journal of Consumer Education, 21, 50-58.

Beckmann, E. (2013), Financial literacy and household savings in Romania. Numeracy, 6(2), Article 9.

Bernama (September 12, 2017). Malaysians are world's largest whatsapp users. Retrieved September 21, 2017, from https://www.nst. com.my/lifestyle/bots/2017/09/278936/malaysia ns-are-wo rlds-largest-whatsapp-users.

Brown, K. M., \& Laschever, R. A. (2012). When they're sixty-four: Peer effects and the timing of retirement. American Economic Journal: Applied Economics, 4(3), 90-115. doi:10.1257/ app.4.3.90.

Brown, S., \& Taylor, K. (2014). Household finances and the "big five" personality traits. Journal of Economic Psychology, 45, 197-212. doi:10. 1016/j.joep.2014.10.006.

Bursztyn, L., Ederer, F., Ferman, B., \& Yuchtman, N. (2012). Understanding peer effects in financial decisions: Evidence from a field experiment (No. w18241). National Bureau of Economic Research.

Cohen, J. (1989). Statistical power analysis for the behavioral sciences (2nd ed.). Hillsdale, NJ: Lawrence Earlbaum Associates.

Cole, S., Sampson, T., \& Zia, B. (2011). Prices or knowledge? What drives demand for financial services in emerging markets? Journal of Finance Finance, 66(6), 1963-1967.

Cude, B. J., Lawrence, F., Lyons, A., Metzger, K., LeJeune, E., Marks, L., \& Machtmes, K. (2006). College students and financial literacy: What they know and what we need to learn. Proceedings of the Eastern Family Economics and Resource Management Association, 102109. 
Danes, S. M., \& Haberman, H. R. (2007). Teen financial knowledge, self-efficacy, and behavior: A gendered view. Financial Counseling and Planning, 18(2), 48-60.

Diamantopoulos, A., \& Siguaw, J. A. (2006). Formative versus reflective indicators in organizational measure development: A comparison and empirical illustration. British Journal of Management, 17(4), 263-282.

Drentea, P. (2000). Age, debt and anxiety. Journal of Health and Social Behavior, 41(4), 437-450.

Drentea, P., \& Lavrakas, P. J. (2000). Over the limit: The association among health status, race and debt. Social Science \& Medicine, 50, 517-529.

Eccles, D. W., Ward, P., Goldsmith, E., \& Arsal, G. (2013). The Relationship between retirement wealth and householders' lifetime personal financial and investing behaviors. Journal of Consumer Affairs, 47(3), 432-464. doi:10.1111/ joca. 12022.

Faul, F., Erdfelder, E., Lang, A.-G., \& Buchner, A. (2007). G*Power 3: A flexible statistical power analysis program for the social, behavioral, and biomedical sciences. Behavior Research $\mathrm{Me}$ thods, 39, 175-191.

Garman, E. T., \& Sorhaindo, B. (2005). Delphi study of experts' rankings of personal finance concepts important in the development of the Incharge financial distress/financial wellbeing scale. Consumer Interests Annual, 51, 184-194.

Gathergood, J. (2012). Self-control, financial literacy and consumer over-indebtedness. Journal of Economic Psychology, 33(3), 590-602.

Gul, F., \& Pesendorfer, W. (2004). Self-control and the theory of consumption. Econometrica, 72(1), $119-158$.

Gutter, M. S., Garrison, S., \& Copur, Z. (2010). Social learning opportunities and the financial behaviors of college students. Family and Consumer Sciences Research Journal, 38(4), 387404.

Hadar, L., Sood, S., \& Fox, C. R. (2013). Subjective knowledge in consumer financial decisions. Journal of Marketing Research, 50(3), 303-316.

Hair, J. F., Hult, G. T. M., Ringle, C. M., \& Sarstedt, M. (2017). A primer on partial least squares structural equation modeling (PLS-SEM). (2nd ed.). Thousand Oaks, California: Sage Publications.

Hastings, J., \& Tejeda-Ashton, L. (2008). Financial literacy, information, and demand elasticity: Survey and experimental evidence from Mexico. NBER Working Paper No. 14538.

Hayduk, L. A., \& Littvay, L. (2012). Should researchers use single indicators, best indicators, or multiple indicators in structural equation mo- dels? BMC Medical Research Methodology, 12 (159).

Hira, T. K. (1997). Financial attitudes, beliefs and behaviors: Differences by age. Journal of Consumer Studies and Home Economics, 21, 271290.

Internet Word Stats (2017). Malaysia Internet Users. Retrieved September 21, 2017, from http://www. internet live stats.com/internet-users/malaysia/.

Jacobson, B. H., Aldana, S. G., Goetzel, R. Z., Vardell, K. D., Adams, T. B., \& Pietras, R. J. (1996). The relationship between perceived stress and self-reported illness-related absenteeism. American Journal of Health Promotion, 54-61.

John, D. R. (1999). Consumer socialization of children: A retrospective look at twenty-five years of research. Journal of Consumer Research, 26, 183-213.

Kernis, M. H., Grannemann, B. D., \& Mathis, L. C. (1991). Stability of self -esteem as a moderator of the relation between level of self-esteem and depression. Journal of Personality and Social Psychology, 61, 80-84.

Klapper, L., Lusardi, A., \& Panos, G. A. (2013), Financial literacy and its consequences: Evidence from Russia during the financial crisis. Journal of Banking and Finance, 37, 3904 3923.

Klapper, L., \& Panos, G. A. (2011), Financial literacy and retirement planning: The Russian case. Journal of Pension Economics and Finance, 10, 599-618.

Laily, N. (2014). Pengaruh literasi keuangan terhadap perilaku mahasiswa dalam mengelola keuangan. JPA UM Malang, 1(4), 277-285.

Landerretche, O. M., \& Martinez, C. (2013). Voluntary savings, financial behavior, and pension finance literacy: Evidence from Chile, Journal of Pension Economics and Finance, 12, 251-297.

Lusardi, A., Mitchell, O. S., \& Curto, V. (2009). Financial literacy among the young: evidence and implication for consumer policy. National Bureau of Economic Research, 34. Retrieved from http://www.dartmouth.edu/ alus ardi/Papers/ Financial_literacy_young.pdf.

Martin, C. A., \& Bush, A. J. (2000). Do role model influence teenagers' purchase intentions and behavior. Journal of Consumer Marketing, 17(5), 441-454.

MetLife Insurance Company. (2003, November). The MetLife study of employee benefits trends: Findings from the 2003 national survey of employers and employees. New York: MetLife Insurance Company. 
McCarthy, Y. (2011). Behavioral characteristics and financial distress. Working Paper Series, 1303, European Central Bank.

Mokhlis, S. (2009). Relevancy and measurement of religiosity in consumer behavior research. International Business Research, 2(3), 75-84.

Németh, E., \& Zsótér, B. (2017). Personality, attitude and behavioral components of financial literacy: A comparative analysis. Journal of Economics and Behavioral Studies, 9(2), 46-57. https://doi. org/10.22610/jebs.v9i2.1649.

O'Neill, B. (2004, December). Small steps to health and wealth. The forum for family and consumer Issues. Retrieved December 29, 2004, from www. ces.ncsu.edu/depts/fcs/pub/9_3/smallsteps.html.

O’Neill, B., Sorhaindo, B., Xiao, J. J., \& Garman, E. T. (2005a). Financially distressed consumers: Their financial practices, financial well-being, and health. Financial Counseling and Planning, 16(1), 73-87.

- (2005b). Health, financial well-being, and financial practices of financially distressed consumers. Consumer Interests Annual, 51, 8082.

------- (2005c). Negative health effects of financial stress. Consumer Interests Annual, 51, 260-262.

Parker, A. M., De Bruin, W. B., Yoong, J., \& Willis, R. (2012) Inappropriate confidence and retirement planning: Four studies with a national sample. Journal of Behavioral Decision Making, 25, 382-389.

Prawitz, A. D., \& Garman, T. E. (2009). It's time to create a financially literate workforce to improve the bottom line. Benefits Compensation Digest, 46(4), 1-6.

Ringle, C., Wende, S., \& Will, A. (2015). SmartPLS 3.0. Retrieved from http:// www.smartpls.com.

Roldán, J. L., \& Sánchez-Franco, M. J. (2012). Variance-based structural equation modeling: Guidelines for using partial least squares. In M. Mora, O. Gelman, A. L. Steenkamp, \& M. Raisinghani (Eds.), Research methodologies, innovations and philosophies in software systems engineering and information systems ( $\mathrm{pp}$. 193-221). Hershey, PA: IGI Global.
Sabri, M. F., \& Falahati, L. (2014). Toward a framework of financial wellness determinants: Investigating the moderating effect of religion. Australian Journal of Basic and Applied Sciences, 8(9), 275-281.

Scott, R. H., III. (2010). Credit card ownership among American high school seniors: 1997-2008. Journal of Family and Economic Issues, 31(2), $151-160$.

Shweder, R. A. (1991). Thinking through cultures: Expeditions in cultural psychology. Cambridge, MA: Harvard University Press.

Socyberty (December 5, 2006). Why do people think work is so important. Cited October 6, 2016 from http://socyber ty.com/work/why-dopeople- think-w ork-is-soimportant/.

Sundarasen, S. D. D., \& Rahman, M. S. (2017). Attitude towards money: Mediation to money management. Academy of Accounting and Financial Studies Journal, 21(1), 1-17.

Thaler, R. H., \& Shefrin, H. M. (1981). An economic theory of self-control. Journal of Political Economy, 89(2), 392-406.

The Malaysian Insider. (2014). Rising trend in youths going bankrupt worrying says minister. Retrieved from http:// www.themalaysianinsider.com/ malaysia/article/rising-trend-in-youths-goingbankrupt-worrying-says-minister -bernama.

Valence, G., d'Astous, A., \& Fourtier, L. (1988). Compulsive buying: Concept and measurement. Journal of Consumer Policy, 11, 419-433.

Yew, S. Y., Yong, C. C., Cheong, K. C., \& Tey, N. P. (2017). Does Financial Education Matter? Education Literacy among Undergraduates in Malaysia. Institutions and Economies, 9(1), 4360.

Yao, R., \& Xu, Y. (2015). Chinese urban households' security market participation: Does investment knowledge and having a long-term plan help? Journal of Family and Economic Issues, 36, 328-339.

Zsótér, B. (2017). Apple from the tree. Intergenerational effects in young adults' financial socialization in family. Doctoral Dissertation. Corvinus University of Budapest, Hungary. 